\title{
A CONCENTRATION OF WHITE-TAILED JACK RABBITS
}

FRED W. LAHRMAN, Saskatchewan Museum of Natural History, Regina, Saskatchewan S4P 3V7.

During the winter of $1978-79$ jack rabbits were seen in large numbers on the fields of the Canada Dept. of Agriculture Research Station, Regina, Saskatchewan, where they tended to gather in groups of 30 to 50 or more. This winter (1979-80) the rabbits gathered there again in similar numbers. This seems to be a local occurrence only. I would guess that the rabbits find these fields attractive because of the abundance of food in the various study plots at the station and the fact that the area is closed to hunting and snowmobiling.

On 23 February 1980, 92 jack rabbits were visible from one vantage point. They were grouped fairly close together with a few stragglers scattered about. No doubt there were others in the vicinity which I missed. On 2 March I counted 110 all bunched together in the same area. On 16 March 42 rabbits were seen. This does not necessarily mean that some had dispersed as later in the day I saw others running to the sanctuary of the field from the nearby Wascana Marsh where snowmobiles could be heard cruising around.

On 16 March there was some evidence of their brown summer pelage starting to appear as some had brown on the ears and faces and one had a veil of light brown on the back. During the afternoon a bitter cold March wind was blowing and it was curious to see all the rabbits facing in the same direction with their backs to the full force of the wind.
None made any attempt to find a sheltered spot.

They were quite wary and any move I made in their direction would send them running in droves like antelope, kicking up a little blizzard of snow as they went.

One strange thing that I noticed about their behavior was that while jack rabbits usually are careful to conceal themselves during the daylight hours, none of the rabbits in these groups did so. They would spend most of their time sleeping huddled up in the open and often individuals within the group would stretch and yawn and hop about visiting back and forth.

\section{FEARLESS JACK RABBITS}

ROBERT KREBA, Saskatchewan Museum of Natural History, Regina, Saskatchewan S4P 3V7.

In connection with Fred Lahrman's report, I would like to describe an encounter of my own with this same "herd" of White-tailed jack rabbits during the Christmas Bird Count, 27 December 1978.

While walking east into the Wascana Country Club property adjacent to the Canada Dept. of Agriculture Research Station, I noticed a man and two boys with an Irish setter and a Labrador retriever. As the dogs ran ahead, they scared a few jack rabbits out of a patch of 